\title{
Recycled Glass Concrete: Coarse and Fine Aggregates
}

\author{
Najib N. Gerges, Camille A. Issa, Samer A. Fawaz, Jacques Jabbour, Johnny Jreige, and Aiman \\ Yacoub
}

\begin{abstract}
Conventional concrete aggregate consists of sand (fine aggregate) and various sizes and shapes of gravel or stones (coarse aggregate). However, there is a growing interest in substituting alternative aggregate materials, largely as a potential use for recycled materials. While there is significant research on many different materials for aggregate substitutes such as granulated coal ash, blast furnace slag or various solid wastes including fiberglass waste materials, granulated plastics, paper and wood products or wastes, sintered sludge pellets and others. Recycled waste glasses were used as coarse and fine aggregates replacement in concrete. Coarse aggregates were replaced with Green Bottles coarse aggregates at third, half, two thirds, and $100 \%$ replacement ratios. The replacement of a third coarse aggregate was established as being the most suitable for retaining the properties of the concrete mix design. As for fine aggregates, in order to account for the numbers of variables and clearly establish a bench mark, the sand grading, color of glass, source of waste glass (bottles and non-bottles), and design mix strength were used as parameters. Fine aggregates from green, brown, and transparent bottles in addition to clear window waste glass were used. Concrete properties were tested in fresh and hardened states. The incorporation of glass sand regardless of the ratios of replacement showed no significant influence on fresh or mechanical properties of concrete except for the case of transparent bottles. Transparent bottles due to the wide source of obtainability have introduced a non-uniform factor that caused discrepancy compared to the rest of the group.
\end{abstract}

Index Terms-Durability; Fresh Concrete; Mechanical Properties; Sand; Waste Glass.

\section{INTRODUCTION}

Post-consumer and other waste glass types are a major component of the solid waste stream in many countries and most is currently landfills [1]. Several European Directives have tackled this problem by setting recovery and recycling targets for specific waste glass streams [2]. EU Landfill Directive and the UK Landfill Tax Regulations [2] have emerged to divert such waste into recovery and recycling programs and, specifically for post-consumer glass, the Packaging Waste Regulations [2] have provided legislative pressure to increase recovery and recycling. Whereas in 2010 in the USA, $11.53 \mathrm{~m}$ tons of waste glasses were generated and only $27.1 \%$ of them were recovered, mostly from containers and packaging [3].

Recovered waste glass can be infinitely re-melted without

Published on January 19, 2018.

N. N. Gerges, S. A. Fawaz, J. Jabbour, J. Jreige, and A. Yacoub are with Civil Engineering, University of Balamand, Balamand, Lebanon. (e-mail: najib.georges@balamand.edu.lb, samer_fawaz@hotmail.com, jacques_jabbour@hotmail.com,_ johnny.jreige@gmail.com, aiman.yacoub@ifsttar.fr)

C. A. Issa is with Civil Engineering, Lebanese American University, Byblos, Lebanon. (e-mail: cissa@lau.edu.lb) degradation of its physical properties and, theoretically at least, the glass manufacturing industry could use $100 \%$ recycled glass as a primary feedstock. However due to tolerances on contamination there is a practical limit and it is estimated [4] that approximately 650,000 tons/year of waste container glass cannot be recycled into new glass manufacture. There is also a rising amount of over $1 \mathrm{~m}$ tons /year from other waste glass streams (e.g. plate glass, windscreens and lighting) that could be recovered and reused.

Alternatively, concrete is the most widely used construction material. The declining supply of natural coarse and fine aggregates and the impact of their extraction on the ecological environment have motivated government, industry, and research institutions to examine the sustainability of concrete. Several sound methods have been proposed to produce concrete without using natural sand, such as sandless concrete, and to use manufactured sand, byproducts, and waste materials as sand replacement [5]-[9]. Among the various waste materials, glass is considered a good substitute for natural sand due to similarities in physical properties and chemical compositions. If this could be accomplished, economical, ecological, and even technical advantages would be realized in the concrete industry, resulting in more savings in energy and raw materials, and reduction in landfills.

Based on the major chemical compositions, glasses can be categorized as soda lime glass, alkali silicates, vitreous silica, borosilicate glass, lead glass, barium glass, and aluminosilicate glass. Soda lime glass, commonly used in the production of containers, float, and windows, constitutes over $80 \%$ of the total waste glass, by weight [10]. Small amounts of additives are added during the production for different colors. The major colors for waste glasses are brown, green, and clear.

The diverse properties of concrete containing glass as sand or fine aggregates at various contents have been studied by several investigations. In general, the properties appear to be encouraging and promising [11]-[14]. Concrete with sand partially replaced by glass particles showed adequate engineering properties, such as compressive and flexural strengths and elastic modulus. Another benefit of using glass sand in concrete is its pozzolanic activity. Fine glass particles exhibit pozzolanic activity because glass is made of amorphous silica. Under alkali attack, the destruction of silica networks releases silica that combines with calcium from Portlandite, forming secondary C-S-H, which can improve the concrete properties. Glass particles could be pozzolanic active if they are sufficiently fine. Shao et al [15] found that glass particles finer than $38 \mu \mathrm{m}(0.0015$ in.) exhibited pozzolanic reaction. In addition, green glass was found to be the most pozzolanic material, followed by 
clear and brown glass [16].

There were, however, some inconsistent and even contradictory test results. For instance, the air content of glassconcrete was reported by Park et al. [17] to consistently increase with higher content of glass sand up to $70 \%$. Topcu and Canbaz, [18] however, reported an uneven decrease in the air content of glass concrete with glass sand content up to $60 \%$. Both groups partially attributed the results to the geometry of glass sand. The irregular shape of crushed glass sand, according to the former group, would retain more air. The poor geometry of glass resulted in less air, according to the latter group.

\section{GLASS AS AGGREGATES FOR CONCRETE}

The use of waste glass as aggregate for concrete has been attempted decades ago. Those early efforts were thwarted by the problem of alkali-silica reaction (ASR), which was not well understood then. It is also expected that the glass aggregate would affect the mechanical properties of the concrete. For example, it is known that the concrete strength is typically controlled by the bond strength between cement matrix and aggregate. If natural aggregate with relatively rough surfaces is replaced by crushed glass particles with relatively smooth surfaces, one would expect a drop in strength and in particular a reduction of an already low ductility. Finally, it was recognized early on that glass concrete is basically a new material that requires the development of appropriate production technologies, as well as answers to other questions that need to be addressed by basic research. Details of the pertinent studies have been documented elsewhere [19]-[23].

\section{RESEARCH SIGNIFICANCE}

The use of recycled glass in concrete opens a vast new market for mixed as well as color sorted broken glass in a variety of specialty products or in local concrete operations. It is the objective of these research findings to help make it possible to utilize glass also in regular concrete applications, thereby expanding and developing markets for recycled glass. Waste glass possesses major problems for municipalities everywhere, and this problem can be greatly eliminated by re-using waste glass as aggregate replacement in concrete. Moreover, there is a limit on the availability of natural aggregate used for making concrete mix, and it is necessary to reduce energy consumption and emission of carbon dioxide resulting from construction processes, solution of this problem are sought thought usages of waste glass as partial replacement of natural coarse and fine aggregates in concrete mixes.

\section{EXPERIMENTAL INVESTIGATION}

In this study, properties of concrete containing recycled glass as fine and coarse aggregates were investigated. These included slump, compressive strength, splitting tensile and flexural strength. Waste glass was either utilized as coarse aggregates or as fine aggregates.

\section{CoARSE AgGREgAtes EXPERIMENTAL StUdy}

Thirty-six concrete cylinders of size $150 \mathrm{~mm}$ by $300 \mathrm{~mm}$ as specified by ASTM C 469 [24] were casted. In Table I the five different categories of coarse aggregates are displayed and the source of glass aggregates was limited to green waste glass bottles. Also included was an additional Specimen No. VI of $100 \%$ glass as fine was added to this series.

The slump test for all concrete mixtures showed no bleeding or segregation during mixing and casting. All concrete mixtures showed slump values of $100 \pm 30 \mathrm{~mm}$ (4 \pm 1.2 in.), meeting the target workability (as shown in Table I), except for Specimen V, which was the least desirable mix as far as strength and workability is concerned. Thus, in general, there was no clear change or trend in the slump values due to incorporation of glass coarse aggregates. Although the sharper edge and more angular shape of crushed glass coarse aggregates would reduce the slump of concrete its impermeable smooth surface may also cause poorer cohesion with cement paste. These two opposing actions would simultaneously result in non-prominent change on slump values. Compared with manufactured aggregates and recycled concrete aggregates, one apparent advantage of glass coarse aggregates is its negligible water absorption capacity. As a result, the glass particles would not absorb water from cement paste, leading to no reduction in workability.

The sieve analysis for the glass coarse aggregates is displayed in Fig. 1 which clearly indicated that the sieve analysis results are within the acceptable range as required by ASTM C136 [25]. Six sets of each specimen types were casted with a water-cement ratio $(\mathrm{w} / \mathrm{c})$ of 0.55 . Three specimens of each type were crushed at 7 days and 28 days. The compressive strength and weight are summarized in Table II, Fig. 2 and 3 compare the seven days' strength to that of the reference mix composed of all natural aggregates at 28 days' strength.

From the results, it can be deduced that best replacement of aggregates among the tested ratios occurs at one third coarse natural aggregates with coarse glass aggregates. The $100 \%$ fine aggregates replacement with glass also does show sign of significant strength. Thus a second series of experiments were conducted based of replacement of fine aggregates.

TABLE I: SPECIMEN TyPES AGGREGATE COMPOSITION AND SLUMP

\begin{tabular}{llllll}
\hline \hline \multirow{2}{*}{ Specimen No. } & \multicolumn{2}{c}{ Coarse Aggregates } & \multicolumn{2}{c}{ Fine Aggregates } & \multirow{2}{*}{ Slump } \\
& Glass & Natural & Glass & Natural & mm \\
\hline I & $0 \%$ & $100 \%$ & $0 \%$ & $100 \%$ & 100 \\
II & $33 \%$ & $67 \%$ & $0 \%$ & $100 \%$ & 100 \\
III & $50 \%$ & $50 \%$ & $0 \%$ & $100 \%$ & 70 \\
IV & $67 \%$ & $33 \%$ & $0 \%$ & $100 \%$ & 70 \\
V & $100 \%$ & $0 \%$ & $0 \%$ & $100 \%$ & 30 \\
VI & $0 \%$ & $100 \%$ & $100 \%$ & $0 \%$ & 90 \\
\hline \hline
\end{tabular}




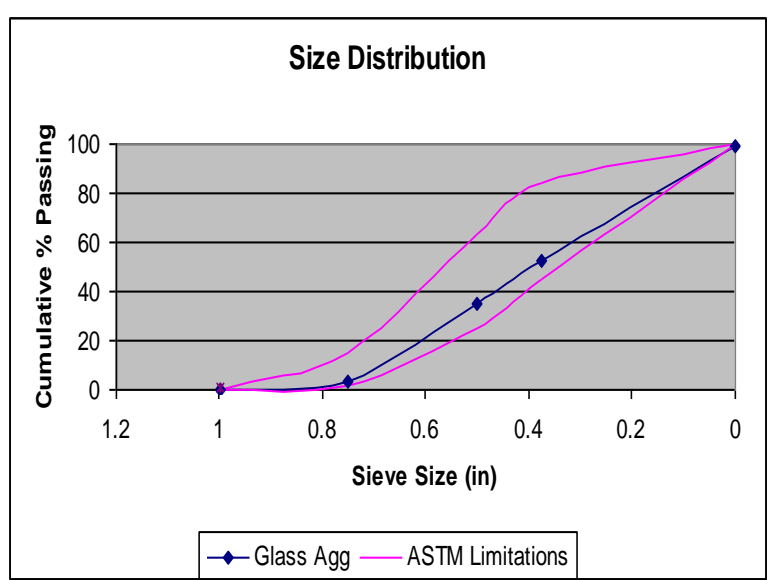

Fig. 1. The sieve analysis of Glass Coarse Aggregates vs. the required ASTM C136 [25] Range

TABLE II: SPECIMEN TYPES: 7 AND 28 DAYS COMPRESSIVE STRENGTH $\left(\mathrm{F}_{\mathrm{C}} \mathrm{C}\right)$

\begin{tabular}{|c|c|c|c|}
\hline $\begin{array}{l}\text { Specimen } \\
\text { Type } \\
\text { Sample No. }\end{array}$ & Weight (g) & $\begin{array}{l}7 \text { Days } \\
\text { Compressive } \\
\text { Strength f'C (MPa) }\end{array}$ & $\begin{array}{l}28 \text { Days } \\
\text { Compressive } \\
\text { Strength f' } \\
\text { (MPa) }\end{array}$ \\
\hline I A & 13000 & 18.6 & 24.8 \\
\hline I B & 13500 & 18.9 & 25.1 \\
\hline I C & 13480 & 19.4 & 25.8 \\
\hline Average & 13327 & 19.0 & 25.2 \\
\hline II A & 13100 & 16.1 & 22.3 \\
\hline II B & 13090 & 17.2 & 23.9 \\
\hline II C & 13250 & 15.8 & 22.0 \\
\hline Average & 13147 & 16.4 & 22.7 \\
\hline III A & 12900 & 14.0 & 19.2 \\
\hline III B & 12890 & 13.4 & 18.4 \\
\hline III C & 13000 & 13.8 & 19.0 \\
\hline Average & 12930 & 13.7 & 18.9 \\
\hline IV A & 13100 & 13.8 & 18.7 \\
\hline IV B & 12500 & 13.5 & 18.2 \\
\hline IV C & 13050 & 13.4 & 18.1 \\
\hline Average & 12883 & 13.5 & 18.3 \\
\hline $\mathbf{V A}$ & 12900 & 8.4 & 10.7 \\
\hline V B & 12950 & 9.5 & 12.1 \\
\hline V C & 12800 & 7.5 & 9.6 \\
\hline Average & 12883 & 8.5 & 10.8 \\
\hline VI A & 12750 & 16.0 & 20.9 \\
\hline VI B & 12900 & 16.1 & 21.0 \\
\hline VI C & 12750 & 16.0 & 20.8 \\
\hline Average & 12800 & 16.0 & 20.9 \\
\hline
\end{tabular}

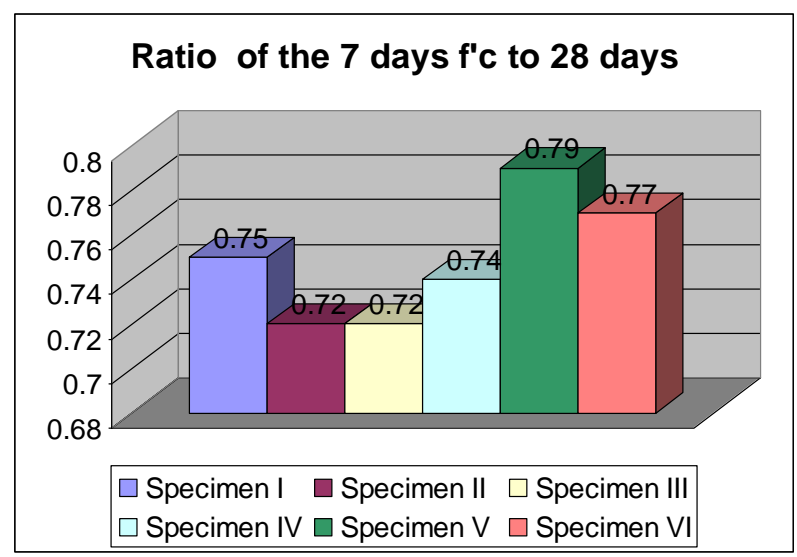

Fig. 2. Ratio of 7 to 28 Days Compressive Strength

\section{Compressive Strength @ 28 days Compared to All Natural Aggregates}

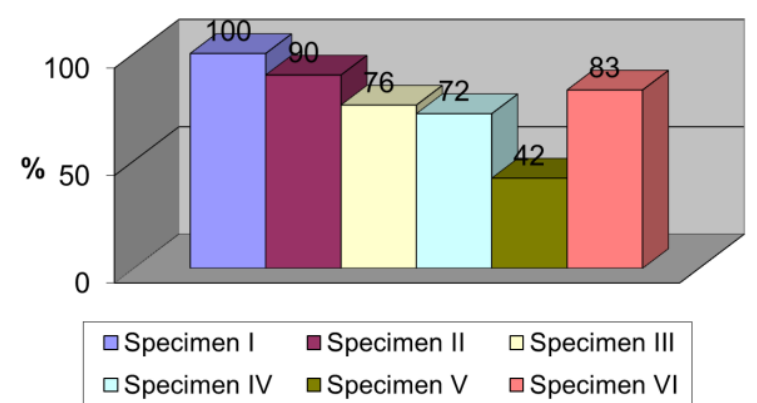

Fig. 3. Compressive Strength Compared to All Natural Aggregates at 28 Days.

The conductivity test was performed on the concrete cylinders before they were crushed at 28 days in order to check if glass, being a good insulator, would play a good role in electrical/sound insulation when placed as glass coarse aggregates in concrete mix. The test is simple and consists of holding the two poles of the conductivity meter, each on a side of the cylinder (Fig. 4) and read the measured reading in micro-seconds. The reading is the time needed for the wave to travel from one pole to the adjacent pole. It can be noted from the values in Fig. 5 that, as expected, as the glass content in the concrete increases, time of travel increases and thus conductivity decreases, thus creating better insulation properties. The conductivity test was only performed on the specimens before they were crushed on 28 days.

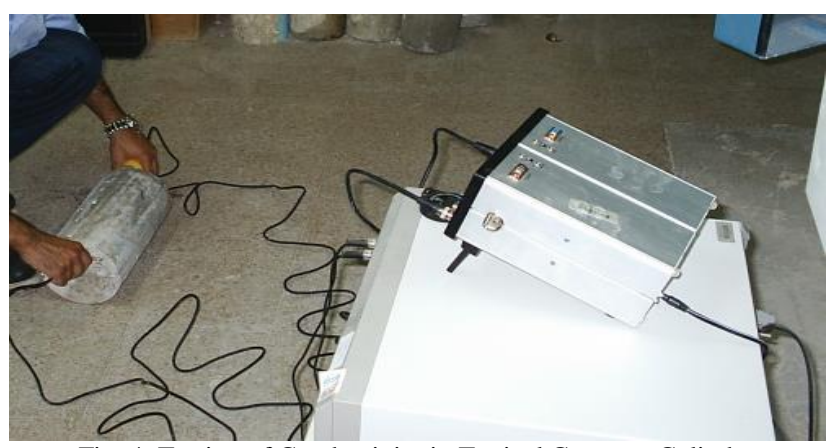

Fig. 4. Testing of Conductivity in Typical Concrete Cylinder

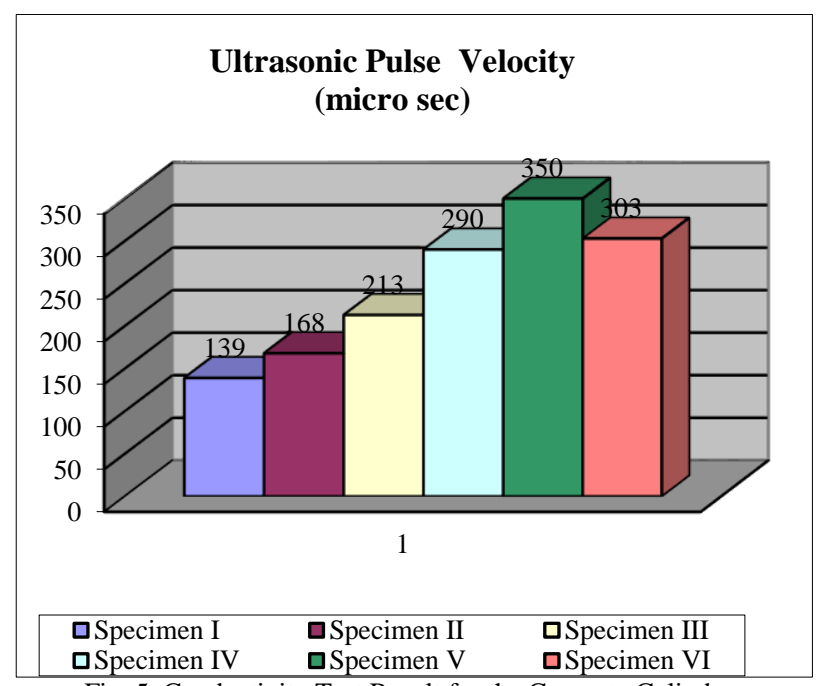

Fig. 5. Conductivity Test Result for the Concrete Cylinders 


\section{FINE AGgREGATES EXPERIMENTAL StUdy}

In the second series of experiments, the objective was to concentrate on the replacement of natural fine aggregates (sand) with waste glass as fine aggregates. Extensive work was already done by Du and Tan [5]-[6], whom reported on the replacement ratio of $0,25,50,75$, and $100 \%$ of sand with fine waste glass and concluded that waste glass can be incorporated into concrete as fine aggregates without deleterious effect on concrete properties of any significance. In order to account for the numbers of variables and clearly establish a bench mark, the sand grading, color of glass, source of waste glass (bottles and non-bottles), and design mix strength were used as parameters. Thus four series of experiments were conducted. Three were waste glass from bottles and the fourth was clear window waste glass. The colors of the waste glass bottles were clear, green, and brown. The results are reported in Table III. These results indicate that neither the replacement ratios nor the design mix strength are affected by using glass, except for clear glass bottles. Clear glass bottles due to the wide source of obtainability have introduced a non-uniform factor that caused discrepancy in strength compared to the rest of the group.

TABLE III: COMPRESSIVE STRENGTH FOR SAND (S) REPLACEMENT WITH GLASS (G) FOR DIVERSE GLASS TYPES AND CONCRETE MIX DESIGNS

\begin{tabular}{|c|c|c|c|c|c|}
\hline \multirow{3}{*}{$\begin{array}{c}\text { Design } \\
\text { (M Pa) } \\
\text { Cylinder }\end{array}$} & \multicolumn{5}{|c|}{ Green Glass Bottles } \\
\hline & \multicolumn{3}{|c|}{ Mix A } & \multicolumn{2}{|c|}{ Mix B } \\
\hline & \multicolumn{2}{|c|}{ 40G60S } & $100 S$ & $40 \mathrm{G60S}$ & $100 S$ \\
\hline 1 & \multicolumn{2}{|c|}{25.9} & 24.4 & 34.9 & 29.3 \\
\hline 2 & \multicolumn{2}{|c|}{26.3} & 27.6 & 32.9 & 35.6 \\
\hline 3 & \multicolumn{2}{|c|}{26.1} & 27.8 & 33.7 & 35.2 \\
\hline Average & \multicolumn{2}{|c|}{26.1} & 26.6 & 33.8 & 33.4 \\
\hline \multirow[t]{2}{*}{$\begin{array}{l}\text { Design } \\
\text { (MPA) }\end{array}$} & \multicolumn{5}{|c|}{ Clear Window Glass } \\
\hline & \multicolumn{3}{|c|}{ Mix A } & \multicolumn{2}{|c|}{ Mix B } \\
\hline Cylinder & \multicolumn{2}{|c|}{$100 \mathrm{~S}$} & 100G & \multicolumn{2}{|c|}{$100 \mathrm{~S} \quad 100 \mathrm{G}$} \\
\hline 1 & \multicolumn{2}{|c|}{29.1} & 29.1 & 34 & 34.1 \\
\hline 2 & & & 28.8 & 34.3 & 34.1 \\
\hline 3 & \multicolumn{2}{|c|}{29.3} & 28.8 & 34.3 & 33.8 \\
\hline Average & \multicolumn{2}{|c|}{29.1} & 28.9 & 34.2 & 34.0 \\
\hline \multirow{2}{*}{$\begin{array}{l}\text { Design } \\
\text { (MPA) } \\
\text { Cylinder }\end{array}$} & \multicolumn{2}{|c|}{$\begin{array}{c}\text { Brown Glass } \\
\text { Bottles }\end{array}$} & \multicolumn{3}{|c|}{ Clear Glass Bottles } \\
\hline & $100 \mathrm{G}$ & $100 \mathrm{~S}$ & $100 \mathrm{G}$ & $100 S$ & 50S50G \\
\hline 1 & 50.9 & 51.4 & 23.6 & 31.0 & ----- \\
\hline 2 & 52.28 & 51.8 & 23.1 & 29.3 & 28.0 \\
\hline 3 & 49.41 & 50.1 & 24.9 & 28.0 & 29.3 \\
\hline Average & 50.86 & 51.1 & 23.9 & 29.4 & 28.7 \\
\hline
\end{tabular}

\section{NON-CONFORMING FInE AND COARSE AGGREGATE EXPERIMENTAL STUDY}

The purpose of this experimental series was to observe how non-conforming glass gradation affects the mechanical properties of concrete mix. In this experimental series, brown-colored, soda-lime glass beer bottles were collected from a local waste recycler. The bottles were soaked in tap water for one day to remove residua. After that, they were air dried and an LA Abrasion machine (Fig. 6), was used to crush the glass bottles. A sieve analysis test was performed in accordance with ASTM C 136[25]. The crushed glass was then collected and screened in a mechanical sieve shaker (Fig. 7) for coarse aggregate size (40mm (1 $1 / 2$ in) $9.5 \mathrm{~mm}(3 / 8 \mathrm{in}))$. The crushed glass retained on designated sieves was then collected for use as coarse aggregate. A sand sieve shaker for fine aggregate was used to grade the fine glass aggregate. Fine glass aggregate for the test shall be passed through $9.5 \mathrm{~mm}$ ( $3 / 8$ in) sieve to satisfy the requirement for sand by ASTM C33 [26]. The grading of the crushed glass sand is shown in Table IV and Fig. 8, whereas the grading curve of crushed glass coarse aggregates are shown Table V and Fig. 9.

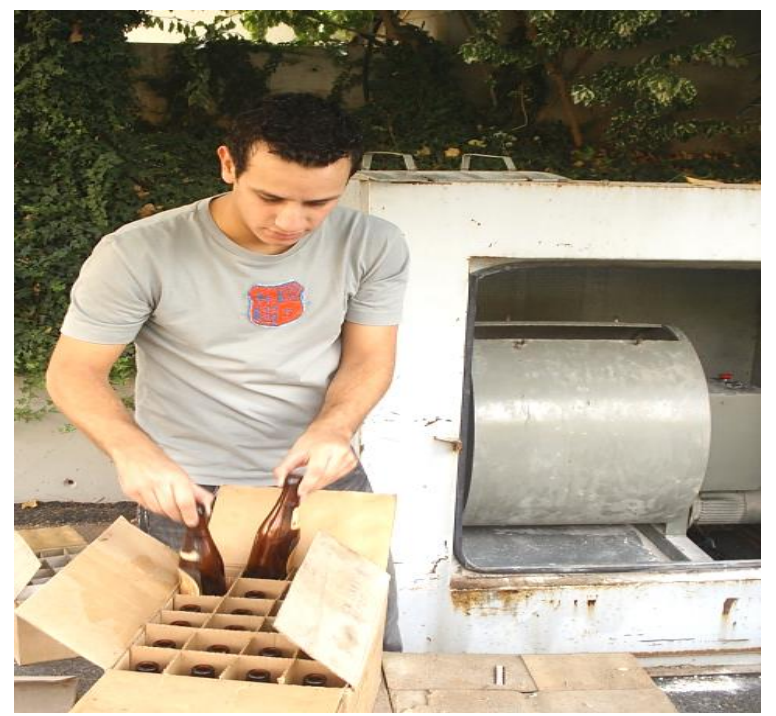

Fig. 6. Crushing the glass bottles mechanical sieve shaker.

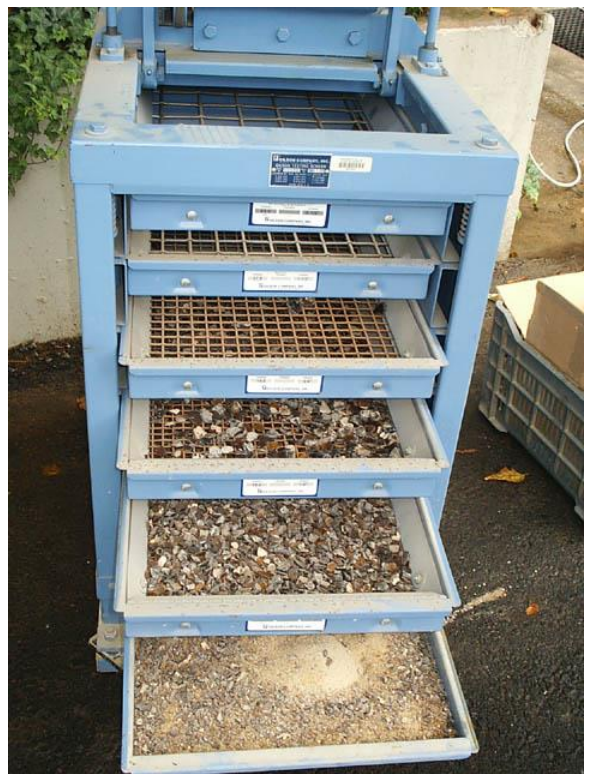

Fig. 7. Crushed glass after sieving in the L.A. Abrasion machine.

TABLE-IV: DETERMINATION OF THE FINENESS MODULUS OF FINE GLASS AGGREGATES

\begin{tabular}{lrrrr}
\hline \hline Sieve Size & $\begin{array}{c}\text { \% of } \\
\text { individual } \\
\text { fraction } \\
\text { retained, } \\
\text { by Mass }\end{array}$ & $\begin{array}{c}\text { Cumulative } \\
\text { \% passing, } \\
\text { by mass }\end{array}$ & $\begin{array}{c}\text { Cumulative } \\
\text { \% } \\
\text { retained, } \\
\text { By mass }\end{array}$ & $\begin{array}{c}\text { ASTM } \\
\text { Limits }\end{array}$ \\
$\begin{array}{l}\text { \% } \\
\text { Passing }\end{array}$ \\
\hline $\mathbf{9 . 5} \mathbf{~ m m ~ ( 3 / 8 ~ i n ) ~}$ & 4.3 & 95.7 & 4.3 & 100 \\
$\mathbf{4 . 7 5} \mathbf{~ m m ~ ( N o ~ . 4 ) ~}$ & 14.8 & 81.0 & 19 & $95-100$ \\
$\mathbf{2 . 3 6} \mathbf{~ m m ~ ( N o ~ . 8 )}$ & 16.3 & 64.7 & 35.3 & $80-100$ \\
$\mathbf{1 . 1 8} \mathbf{~ m m ~ ( N o ~ . 1 6 )}$ & 14.8 & 49.9 & 50.1 & $50-85$ \\
\hline \hline
\end{tabular}




\begin{tabular}{lrrrc}
\hline \hline $\mathbf{6 0 0} \boldsymbol{\mu m}($ No .30) & 19.4 & 30.5 & 69.5 & $25-60$ \\
$\mathbf{3 0 0} \boldsymbol{\mu m}($ No .50) & 19.6 & 10.9 & 89.1 & $5-30$ \\
$\mathbf{1 5 0} \boldsymbol{\mu m}($ No .100) & 9.8 & 1.1 & 98.9 & $0-10$ \\
Pan & 1.0 & 0 & 100 & \\
Total & 100 & & & \\
\multicolumn{4}{l}{ Fineness Modulus $\boldsymbol{F M}=466 \div 100=4.66$} \\
\hline \hline
\end{tabular}

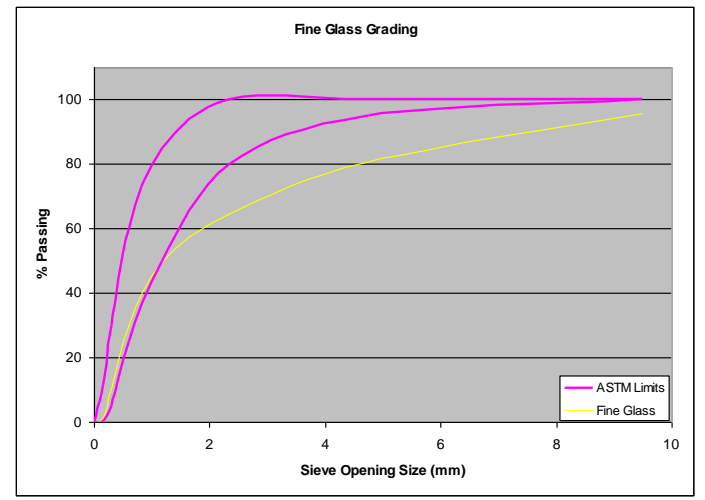

Fig. 8. Grading curves for glass fine aggregates

TABLE V: GRADING RESUlTS OF COARSE GLASS AGGREGATES

\begin{tabular}{|c|c|c|c|c|}
\hline Sieve Size & $\begin{array}{c}\% \text { of } \\
\text { individual } \\
\text { fraction } \\
\text { retained, by } \\
\text { Mass }\end{array}$ & $\begin{array}{c}\text { Cumulative } \\
\% \text { passing, } \\
\text { by mass }\end{array}$ & $\begin{array}{c}\text { Cumulative } \\
\text { \% retained, } \\
\text { By mass }\end{array}$ & $\begin{array}{c}\text { ASTM } \\
\text { Limits } \\
\% \\
\text { Passing }\end{array}$ \\
\hline $\begin{array}{l}25 \mathrm{~mm} \\
(1 \mathrm{in})\end{array}$ & 12.2 & 87.8 & 12.2 & $90-100$ \\
\hline $\begin{array}{l}19.0 \mathrm{~mm} \\
(3 / 4 \mathrm{in})\end{array}$ & 19.3 & 68.4 & 31.6 & $40-85$ \\
\hline $\begin{array}{l}12.5 \mathrm{~mm} \\
(1 / 2 \mathrm{in})\end{array}$ & 21.5 & 47.0 & 53.0 & $20-60$ \\
\hline $\begin{array}{l}9.5 \mathrm{~mm} \\
(3 / 8 \mathrm{in})\end{array}$ & 9.6 & 37.4 & 62.6 & $0-5$ \\
\hline Pan & 37.4 & 100.0 & 0.0 & \\
\hline Total & 100 & & & \\
\hline
\end{tabular}

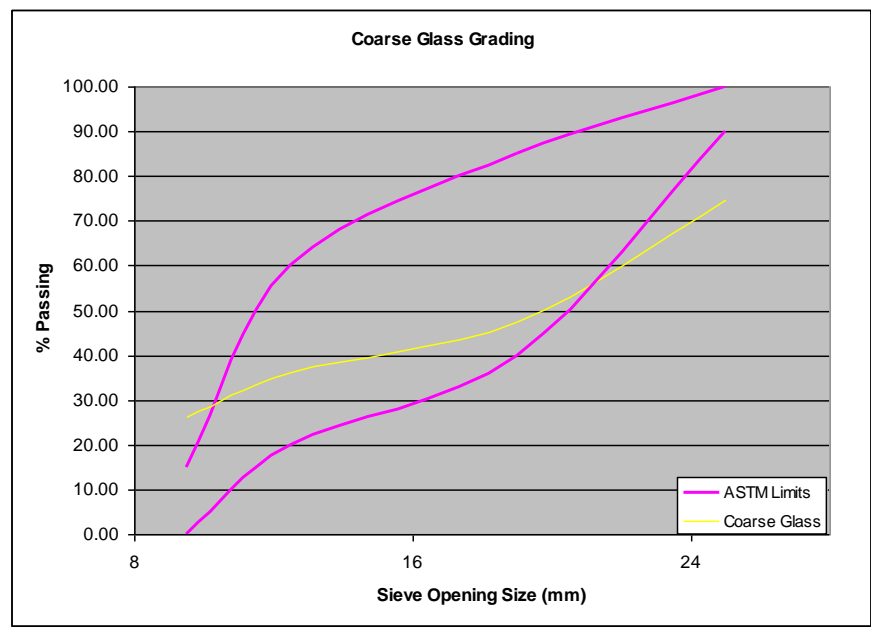

Fig. 9. Grading curves of glass coarse aggregates

The density of the coarse aggregate was $2650 \mathrm{Kg} / \mathrm{m} 3$ and of the fine aggregate was $1680 \mathrm{Kg} / \mathrm{m} 3$, whereas the colored glass had a density of $1650 \mathrm{Kg} / \mathrm{m} 3$. Three batches were designed whereby the first batch, labeled R, consists of a regular mix. The second batch labeled $\mathrm{C} 13$, consists of $13 \%$ of coarse crushed glass substituting the coarse aggregates and finally the third batch labeled F15 consists of $15 \%$ of fine crushed glass substituting the fine aggregates. Table IV shows the proportioning of raw material used in the mix designs. The concrete mix design was casted with a watercement ratio $(\mathrm{w} / \mathrm{c})$ of 0.34 . From each batch five cylinders were casted, three specimens for compression test and two for the splitting tensile strength (ASTM C78 [27]). Also, six beams $150 \mathrm{~mm}$ by $150 \mathrm{~mm}$ by $450 \mathrm{~mm}$ were casted, two from each batch on which flexural strength was performed according to ASTM C496 [28]. The slump test is generally the most accepted method used to measure consistency. The slump test was performed according to ASTM 143 [29] on each of the batches to check the workability of the mix. The Slump test results (Table IV) showed that the slump value obtained from $13 \%$ substitution of the coarse aggregate with the coarse crushed glass was equal to the one obtained with the $15 \%$ substitution of the fine aggregate with the fine crushed glass. There is no correlation between batches having same slump, but this gives an idea about the interlocking action caused by the crushed glass. The interlocking action has slight effect on slump due to the small proportion of glass aggregate in both batches.

\begin{tabular}{|c|c|c|c|}
\hline Batch Label & $\begin{array}{c}\text { Cement } \\
(\mathrm{Kg})\end{array}$ & $\begin{array}{c}\text { Water } \\
(\text { Kg) }\end{array}$ & $\begin{array}{c}\text { Crushed Agg. } \\
(\mathrm{Kg})\end{array}$ \\
\hline $\mathbf{R}^{*}$ & 350 & 120 & 300 \\
\hline $\mathrm{C13}^{* *}$ & 350 & 120 & 300 \\
\hline $\mathbf{F} 15^{* * *}$ & 350 & 120 & 300 \\
\hline $\begin{array}{c}\text { Batch } \\
\text { Label }\end{array}$ & $\begin{array}{c}\text { Coarse Agg. } \\
(\mathrm{Kg})\end{array}$ & $\begin{array}{c}\text { Fine Agg. } \\
(\mathrm{Kg})\end{array}$ & $\begin{array}{c}\text { Coarse Crushed } \\
\text { Glass (Kg) } \\
\end{array}$ \\
\hline $\mathbf{R}^{*}$ & 700 & 450 & - \\
\hline $\mathrm{C13}^{* *}$ & 643 & 450 & 57 \\
\hline $\mathrm{F}^{*} 5^{* * *}$ & 700 & 384 & \\
\hline \multicolumn{2}{|c|}{ Batch Label } & $\begin{array}{l}\text { Crushed Glass } \\
\text { (Kg) }\end{array}$ & $\begin{array}{c}\text { Slump } \\
(\mathbf{m m})\end{array}$ \\
\hline \multicolumn{2}{|l|}{$\mathbf{R}^{*}$} & - & VIII. 100 \\
\hline \multicolumn{2}{|l|}{$\mathrm{C} 3^{* * *}$} & - & IX. 90 \\
\hline \multicolumn{2}{|l|}{ F15 $^{* * *}$} & 66 & X. 90 \\
\hline
\end{tabular}

* R: Regular mix design ${ }^{* *}$ C13: Coarse glass substituting $13 \%$ of coarse aggregate by volume ${ }^{* * *}$ F15: Fine glass substituting $15 \%$ of fine aggregate by volume

In the compression test the extensometers (Fig. 10) were utilized to record the horizontal and vertical displacement in $\mathrm{mm}$ thus reflecting the variation in the expansion and compression and these were recorded at one second time interval. The compressive strength for the cylinders ae displayed in Table VII. The stress strain curves for compressive strength test are shown in Fig. 11. 


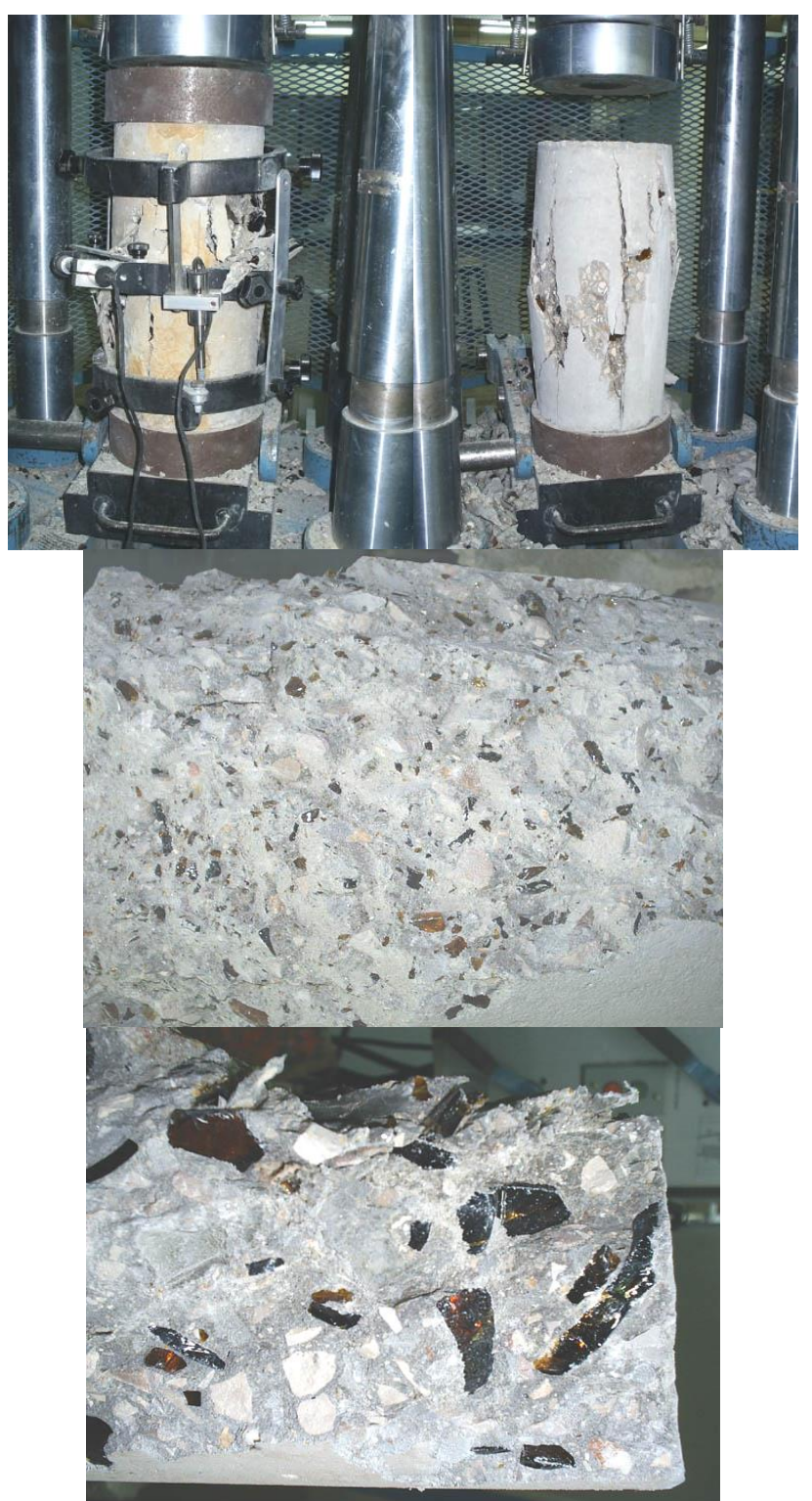

Fig. 10. Compression test on cylinders from batches R, F15 and C13.

TABLE VII: COMPRESSIVE STRENGTH $F_{C}{ }_{C}$

\begin{tabular}{cccc}
\hline \hline \multirow{2}{*}{ Specimen \# } & \multicolumn{3}{c}{$\boldsymbol{f}^{\prime}$ (MPa) } \\
& $\mathbf{R}$ & $\mathbf{F 1 5}$ & $\mathbf{C 1 3}$ \\
\hline $\mathbf{1}$ & 40.0 & 31.1 & 24.2 \\
$\mathbf{2}$ & 38.0 & 32.3 & 24.7 \\
$\mathbf{3}$ & 38.7 & 31.8 & 23.9 \\
Average & $\mathbf{3 8 . 9}$ & $\mathbf{3 1 . 7}$ & $\mathbf{2 4 . 3}$ \\
\hline \hline
\end{tabular}

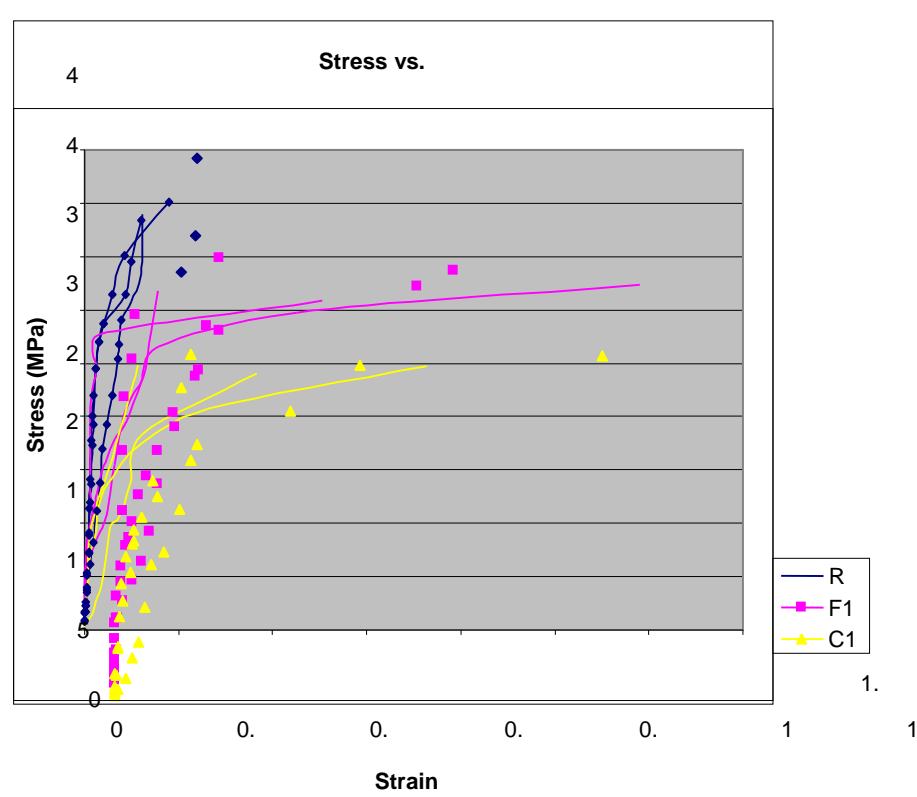

Fig. 11. Stress vs. Strain

The flexural strength of the concrete mixes was measured to according to ASTM C 78 [27] (Fig. 12). From obtained results displayed in Table VIII, for both batches, glass has decreased the flexural load-carrying capacity of concrete. Results are calculated and reported as the modulus of rupture.

\begin{tabular}{cccc}
\multicolumn{4}{c}{ TABLE VIII: MODULUS OF RUPTURE R } \\
\hline \hline \multirow{2}{*}{ Specimen \# } & \multicolumn{3}{c}{ Modulus of Rupture (MPa) } \\
& $\mathbf{R}$ & $\mathbf{F 1 5}$ & $\mathbf{C 1 3}$ \\
\hline $\mathbf{1}$ & 6.2 & 5.6 & 5.1 \\
$\mathbf{2}$ & 7.0 & 5.9 & 5.5 \\
$\mathbf{3}$ & 6.5 & 5.5 & 5.3 \\
Average & 6.6 & 5.7 & 5.3 \\
\hline \hline
\end{tabular}
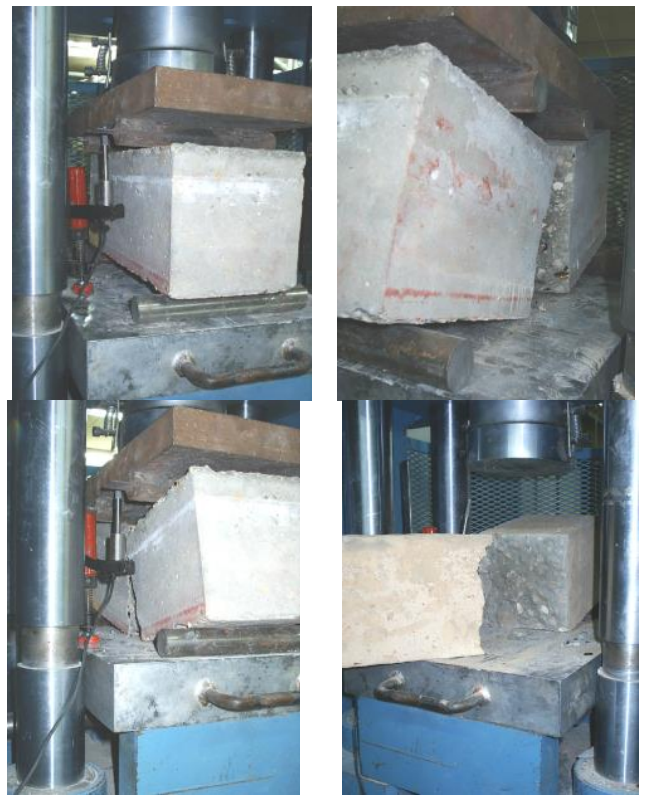


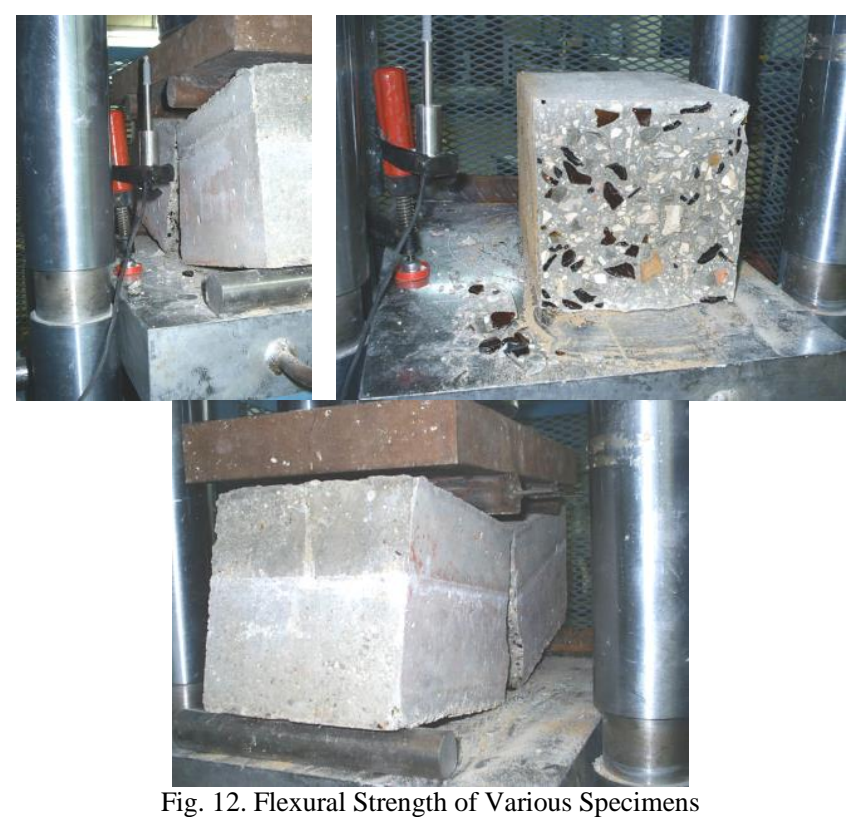

The splitting tensile strength test method was used for determination of the tensile strength of concrete in accordance with ASTM C496 [28]. The method consists of applying a diametric compressive force along the length of a cylindrical concrete specimen (Fig. 13). This loading induces tensile stress on the plane containing the applied load and relatively high compressive stresses in the area immediately around the applied load. Tensile failure occurs rather than compressive failure because the areas of load application are in state of triaxial compression, thereby allowing them to withstand much higher compressive stresses than would be indicated by a uniaxial compressive strength test result. Table IX shows the results of the splitting tensile strength test performed on specimens cast from batches R, C13 and F15.

The direct tensile strength of concrete is about 8 to $12 \%$ of the compressive strength and is often estimated as 0.4 to 0.7 times the square root of the compressive strength in $\mathrm{MPa}$. By applying the previous formula on values in Table VIII we can deduce that results are comparable, which means a consistency in results of the tested specimens. Lack of widespread reliable data on aggregate substitutes can hinder its use. To design consistent, durable recycled aggregate concrete, more testing is required to account for variations in the aggregate properties.
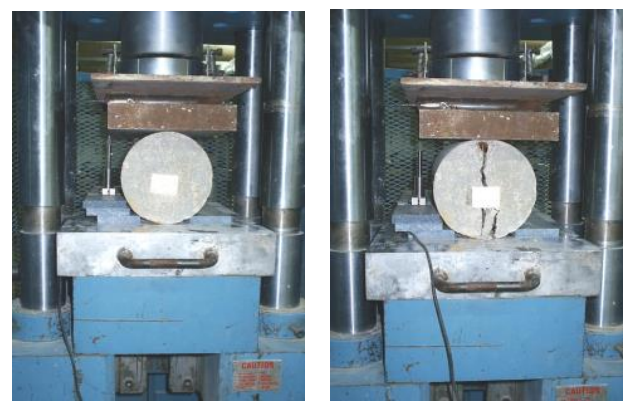

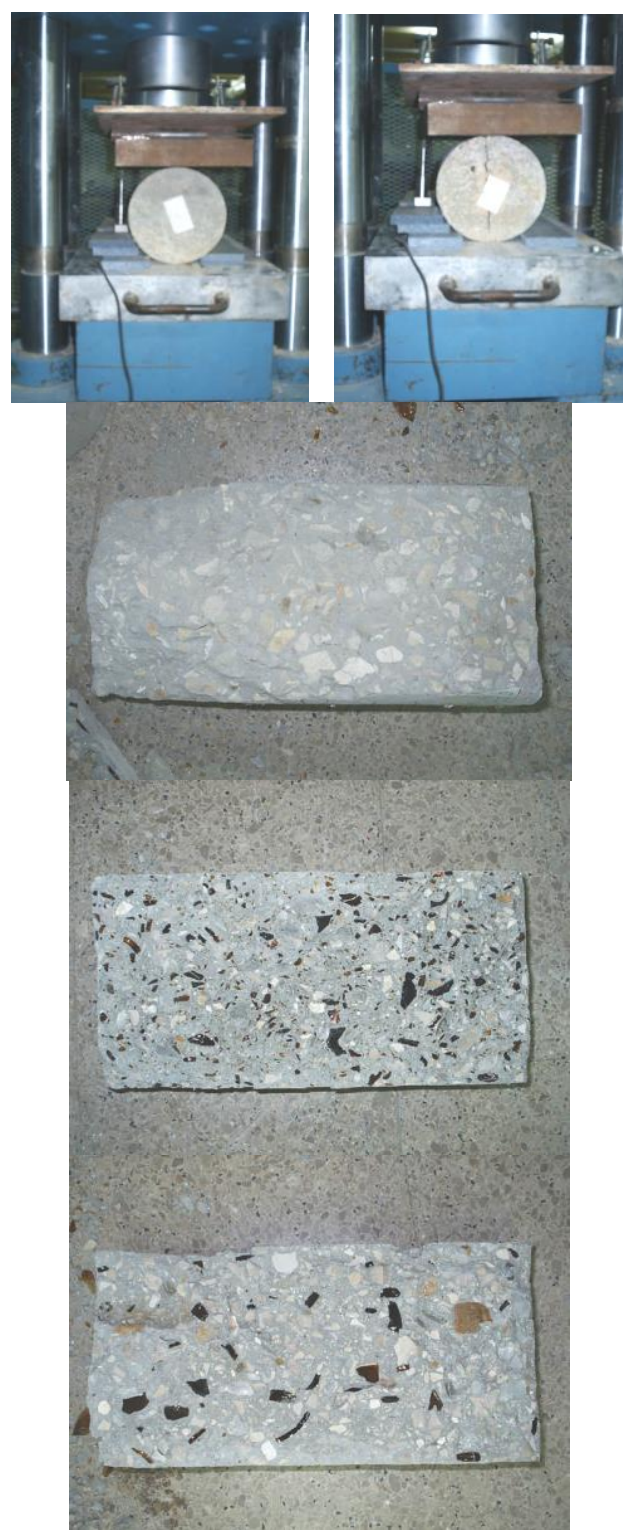

Fig. 13. Splitting tensile strength test

TABLE IX: SPLITTING TENSILE STRENGTH Splitting Tensile Strength in MPa

\begin{tabular}{cccc} 
Specimen \# & R & F15 & C13 \\
\hline $\mathbf{1}$ & 3.6 & 2.7 & 2.2 \\
$\mathbf{2}$ & 3.4 & 2.8 & 2.5 \\
Average & 3.5 & 2.8 & 2.3 \\
\hline \hline
\end{tabular}

\section{CONCLUSION}

In this study, recycled glass particles were used to replace natural sand and crushed stones as fine aggregates and coarse aggregates in concrete mix design. The following conclusions can be drawn from the experimental studies.

\section{A. For Glass Fine Aggregates (Glass Sand):}

- Glass sand had no obvious effect on the fresh properties of concrete; that is, only a slight reduction in fresh density, a marginal increase in air content, and negligible change in slump were observed; 
- Up to $100 \%$ replacement ratio, glass sand did not reduce the mechanical properties of concrete. On the contrary, it led to an increase in compressive strength, splitting tensile strength, flexural strength, and static modulus. The drying shrinkage was slightly reduced with the use of glass sand in lower-strength concrete;

- The output results revealed that using fine waste glass within the concrete mix lead to a comparatively slight reduction in the mix workability for water cement ratios 0.5 and 0.6. Also, it was noticed that the coarse waste glass content almost did not affect the workability of the concrete mix at water cement ratio of 0.4 .

\section{B. For Glass Fine Aggregates (Glass Sand):}

- For concrete mixes containing coarse waste glass, it was concluded that there were negligible effects on the compressive strength, the splitting tensile and flexural strength of the mix.

- The compressive strength of concrete with glass as coarse aggregates is reduced due to the smoothness in the surface leads to a weaker bonding effect between glass and cement, whereas the roughness creates a good higher binding between aggregate and the cement.

- Although glass appears to be a solid, that is not really accurate. Technically, glass is considered a liquid. In a liquid, the molecules are connected in no special way. Solids, like sand, have an ordered molecular structure.

- As a general outcome, it was noticed that the concrete mass density was decreased by the increase of water cement ratio. More specifically, for the concrete with water cement ratio of 0.6 , the concrete mass density decreased when the portion of coarse waste glass exceeded 0.4 .

- In summary, recycled waste glass can be incorporated into concrete as fine aggregates, up to $100 \%$ replacement ratio, without deleterious effect on concrete properties. Because glass does not contain planes of atoms that can slip past each other, there is no way to relieve stress. Excessive stress therefore forms a crack that starts at a point where there is a surface flaw. Particles on the surface of the crack become separated. The stress that formed the crack is now borne by particles that have fewer neighbors over which the stress can be distributed. Growth in the crack causes the intensity of the stress at its tip to increase. This allows more bonds to break, and the crack widens until the glass breaks.

- The usage of glass into fine aggregate may be explained as economical lightweight filler. The glass used may be worth investigation in thermal insulation concrete to a certain extent and may be used for lightweight concrete, yet stability and quality control of the product must be provided.

In summary, recycled waste glass can be incorporated into concrete as fine aggregates, up to $100 \%$ replacement ratio, without deleterious effect on concrete properties.
Because glass does not contain planes of atoms that can slip past each other, there is no way to relieve stress. Excessive stress therefore forms a crack that starts at a point where there is a surface flaw. Particles on the surface of the crack become separated. The stress that formed the crack is now borne by particles that have fewer neighbors over which the stress can be distributed. Growth in the crack causes the intensity of the stress at its tip to increase. This allows more bonds to break, and the crack widens until the glass breaks.

The usage of glass into fine aggregate may be explained as economical lightweight filler. The glass used may be worth investigation in thermal insulation concrete to a certain extent and may be used for lightweight concrete, yet stability and quality control of the product must be provided.

\section{REFERENCES}

[1] Shao, Y., Lefort, T., Moras, S., and Rodriguez, D. "Studies on Concrete Containing Ground Waste Glass", Cement and Concrete Research, Vol. 30, 2000, pp 91-100.

[2] Byars, E.A., Zhu H.Y., and Morales, B., "Conglasscrete I", www.wrap.org.uk.

[3] U.S. Environmental Protection Agency, Office of Resource Conservation and Recovery, "Municipal Solid Waste Generation, Recycling, and Disposal in the United States Tables and Figures for 2010," 2011, 58 pp.

[4] The Waste Resource Action Program, "Recycled Glass Market Study \& Standard Review - 2003 Update”, www.wrap.org.uk.

[5] Tan, K. H., and Du, H., "Towards a Sustainable Concrete: 'Sandless' Concrete," Science and Engineering of Composite Materials, V. 18, No. 1-2, 2011, pp. 99-107.

[6] Tan, K. H., and Du, H., "Sandless Concrete with Fly Ash as Supplementary Cementing Material," Journal of Sustainable CementBased Materials, V. 2, No. 3-4, pp. 238-249.

[7] Frank, P., and Nichols, J., "Manufactured Sand and Crushed Stone in Portland Cement Concrete," Concrete International, V. 4, No. 8, Aug. 1982, pp. 56-63.

[8] Siddique, R., "Effect of Fine Aggregate Replacement with Class F Fly Ash on the Abrasion Resistance of Concrete," Cement and Concrete Research, V. 33, No. 11, 2003, pp. 1877-1881.

[9] Meyer, C., "The Greening of the Concrete Industry," Cement and Concrete Composites, V. 31, No. 18, 2009, pp. 601-605.

[10] Shi, C., and Zheng, K., "A Review on the Use of Waste Glasses in the Production of Cement and Concrete," Resources, Conservation and Recycling, V. 52, No. 2, 2007, pp. 234-247.

[11] Meyer, C., and Xi, Y., "Use of Recycled Glass and Fly Ash for Precast Concrete," Journal of Materials in Civil Engineering, V. 11, No. 2, 1999, pp. 89-90.

[12] Polley, C.; Cramer, S. M.; and Cruz, R. V., "Potential for Using Waste Glass in Portland Cement Concrete," Journal of Materials in Civil Engineering, V. 10, No. 4, 1998, pp. 210-219

[13] Shayan, A., and Xu, A., "Value-Added Utilization of Waste Glass in Concrete," Cement and Concrete Research, V. 34, No. 5, 2004, pp. 81-89.

[14] Berry, M.; Stephens, J.; and Cross, D., "Performance of 100\% Fly Ash Concrete with Recycled Glass Aggregate," ACI Materials Journal, V. 108, No. 4, July-Aug. 2011, pp. 378-384.

[15] Shao, Y.; Lefort, T.; Moras, S.; and Rodriguez, D., "Studies on Concrete Containing Ground Waste Glass", Cement and Concrete Research, V. 30, No. 1, 2000, pp. 91-100.

[16] Karamberi, A., and Moutsatsou, A., "Participation of Coloured Glass Cullet in Cementitious Materials," Cement and Concrete Composites, V. 27, No. 2, 2005, pp. 319-327.

[17] Park, S. B.; Lee, B. C.; and Kim, J. H., "Studies on Mechanical Properties of Concrete Containing Waste Glass Aggregate," Cement and Concrete Research, V. 34, No. 12, 2004, pp. 2181-2189.

[18] Topcu, I. B., and Canbaz, M., "Properties of Concrete Containing Waste Glass," Cement and Concrete Research, V. 34, No. 2, 2004, pp. 267-274.

[19] Meyer, C. and Baxter, S., "Use of Recycled Glass for Concrete Masonry Blocks", Final Report 97-15, New York State Energy Research and Development Authority, Albany, NY, November 1997.

[20] Meyer, C. and Baxter, S., "Use of Recycled Glass and Fly Ash for Precast Concrete", Final Report 98-18, New York State Energy Research and Development Authority, Albany, NY, October 1998. 
[21] Meyer, C., "Development of Glass Concrete Products", Final Report to Office of Recycling Market Development, New York State Department of Economic Development, Albany, NY, March 1999.

[22] Jin, W., "Alkali-Silica Reaction in Concrete with Glass Aggregates A Chemo-Physico-Mechanical Approach", Ph.D. Dissertation, Columbia University, 1998.

[23] Jin, W., Meyer, C. and Baxter, S., "Glascrete - Concrete with Glass Aggregate", ACI Materials Journal, March-April 2000.

[24] ASTM C469, "Standard Test Method for Static Modulus of Elasticity and Poisson's Ratio of Concrete in Compression," ASTM International, West Conshohocken, PA, 2002, 5 pp.

[25] ASTM C 136, "Standard Test Method for Sieve Analysis of Fine and Coarse Aggregates," ASTM International, West Conshohocken, PA, 2002, 5 pp.

[26] ASTM C33, "Standard Specification for Concrete Aggregates," ASTM International, West Conshohocken, PA, 2003, 11 pp.

[27] ASTM C78, "Standard Test Method for Flexural Strength of Concrete," ASTM International, West Conshohocken, PA, 2002, 3 pp

[28] ASTM C 496/C496M, "Standard Test Method for Splitting Tensile Strength of Cylindrical Concrete Specimens," ASTM International, West Conshohocken, PA, 2004, 5 pp.

[29] ASTM C 143/C143M, "Standard Test Method for Sump of Hydraulic-Cement Concrete," ASTM International, West Conshohocken, PA, 2005, 4 pp.

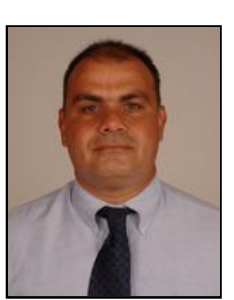

Najib N. Gerges, Associate Professor of Civil Engineering, University of Balamand, Balamand, Lebanon.

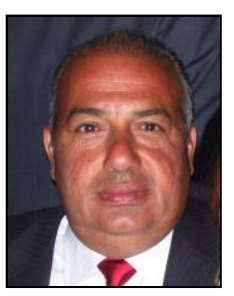

Camille A. Issa, Professor of Civil Engineering, Lebanese American University, Byblos, Lebanon. cissa@lau.edu.lb

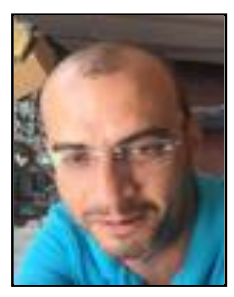

Samer A. Fawaz, Ph.D. Candidate Civi Engineering, University of Balamand, Balamand, Lebanon

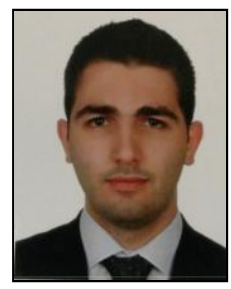

Jacques Jabbour, Ph.D. Candidate Civil Engineering, University of Balamand, Balamand, Lebanon

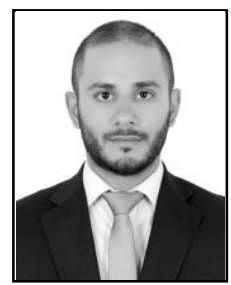

Johnny Jreige, Ph.D. Candidate Civil Engineering, University of Balamand, Balamand, Lebanon

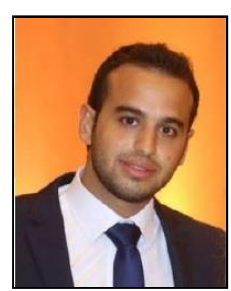

Aiman Yacoub, Ph.D. Candidate Civil Engineering, University of Balamand, Balamand, Lebanon 